\title{
Using data from collective hunts to estimate the wild boar (Sus scrofa) population density in north-eastern Poland
}

\author{
Bogusław Bobek $^{1}$ (D Jakub Furtek ${ }^{2} \cdot$ Marta Wojciuch-Płoskonka $^{2}$
}

Received: 11 January 2021 / Accepted: 1 September 2021 / Published online: 28 September 2021

(c) The Author(s) 2021

\begin{abstract}
The spread of the African swine fever through wild boar population has caused major losses in the pig industry. Therefore, to decrease the population density of wild boar in Poland, the culling of these animals has been dramatically increased. However, the effect of depopulation is unknown because there are no methods that could be used throughout the country to estimate the number of wild boar. Thus, during two hunting seasons an attempt was made to estimate the number of wild boar using data from collective hunts. The forested area of 21 hunting districts $\left(351.5 \mathrm{~km}^{2}\right)$ was divided into five sampling inventory blocks (SIBs), which were used for the statistical analysis of the population density, the harvest rate and results of collective hunts. The average population density obtained by a driving census amounted to $8.19 \pm 1.12$ and $10.09 \pm 1.06$ ( $\overline{x \pm S E}$ ), animals $/ \mathrm{km}^{2}$, which indicates that 2879 and 3547 wild boar were living in the study area in 2012/2013 and 2013/2014 seasons respectively. The number of wild boars bagged per one hunting plot was adopted as the harvest success index (HBI). In SIBs the HBI value fluctuated in the range of 0.55 to 1.87 individuals/hunting plot and the population density ranged from 6.46 to 12.18 wild boars $/ \mathrm{km}^{2}$. The non-linear regression showed a positive relationship between the HBI index and the population density. The discussion covers the possibility of using collective hunts to estimate the number of wild boar in Poland and in the European Union.
\end{abstract}

Keywords Collective hunts · Driving census $\cdot$ Harvest success $\cdot$ Harvest rate $\cdot$ Poland $\cdot$ Population density $\cdot$ Rate of increase $\cdot$ Sus scrofa

\section{Introduction}

In Poland, game animals are not the property of landowners, but are national property. Game management is conducted within 4691 hunting districts covering a combined total of $256,183 \mathrm{~km}^{2}$ and $82 \%$ of Poland's national territory (Central Statistical Office 2020). Hunting districts are leased to hunting clubs for 10 years period. Hunting clubs are nongovernmental organisations with the status of legal persons. They are obliged to carry out comprehensive game management on the leased areas, which involves taking inventories

Handling editor: Mauro Lucherini.

Bogusław Bobek

b.bobek@o2.pl

1 Institute of Biology, Pedagogical University, Podchorążych 2, 30-084 Kraków, Poland

2 Polish Wildlife Foundation, Żołnierska 31, 30-735 Kraków, Poland of game animals, setting and implementing the monitoring of hunting bags as well as paying compensation for damage made by wild ungulates in cultivated fields (Okarma and Tomek 2008). In Poland, the hunting season for wild boar (Sus scrofa) lasts the whole year, i.e. from the beginning of March to the end of February the following year, but collective hunts are limited to 4 months from October to January next year. Under the provisions of the Polish Hunting Law, hunting clubs are obligated to present the population number and hunting bag at the beginning of the hunting season. The population size and the harvest management plans are authorised annually by state and local government administration bodies (Przybylski 2015).

The numbers of wild boar are determined by hunters arbitrarily and they are based on guesstimation and lack any calculation methodology (Pucek et al. 1975; CharmierCiemiński et al. 2009). For this reason, they barely reflect the actual population numbers. Often, the area of a hunting district is too small and does not cover the all-year living areas of local populations. The seasonal differences of the 
potential food base and the thermal hiding cover that can be noted particularly in various habitats of field-forest mosaic are the reasons for local movements of wild boar between some hunting districts. The population numbers submitted by hunting clubs in March very often represent the wild boar numbers which, according to the guesstimation of hunters, occur in the hunting season. As a result, the data pertaining to the numbers of wild boar in Poland published by Central Statistical Office (2020) based on the data obtained from hunting clubs are of limited credibility and contain errors of unknown size. The estimations made with the use of sampling plots showed that in several regions of Poland, the wild boar population density is higher by an average of 35\% than the official hunting statistics (Bobek et al. 2013).

The spread of African swine fever (ASF) among wild boar has caused major losses in the East European pig industry (Guinat et al. 2016; Pejsak et al. 2018; Cwynar et al. 2019; Flis 2020). Expert analysis commissioned by the European Union and result of field studies showed that the wild boar population density is the main risk factor in the occurrence of ASF within the population of the species (Boklund et al. 2018; Fernandez-Lopez et al. 2020; Podgórski et al. 2020).

Facing the current expansion of the ASF virus in Poland (Śmietanka et al. 2016) to reduce the population density the wild boar harvesting figures were statistically moved upward. For instance, between 2018/2019 and 2019/2020 hunting seasons, the annual hunting bag increased from 226 to 332 thousand animals (Central Statistical Office 2020). The effects of the action can only be known via obtaining estimates of population numbers using well documented objective methods.

The authors of numerous publications have suggested that the size of the wild boar harvest should be related to the population number (Acevedo et al. 2006; Imperio et al. 2010; Massei et al. 2015; Keuling et al. 2018). For this reason, we hypothesize that the number of wild boar harvested in collective hunts is positively correlated with the population density. We have submitted the above hypothesis to the test in the hunting districts situated in north-eastern Poland.

\section{Study area}

The study area situated in north-eastern Poland (Fig. 1) covers $1345.3 \mathrm{~km}^{2}$ of which $26.1 \%\left(351.5 \mathrm{~km}^{2}\right)$ are forest habitats. Its elevation ranges between 20 and $190 \mathrm{~m}$ above sea level, the vegetation period lasts 190-210 days and the annual mean temperature averages $7.5^{\circ} \mathrm{C}$ (Woś 1999; Starkel 1991).

The study area is characterized by a large number of fragmented forest $(n=436)$ administrated by the Młynary Forest District and Zaporowo Forest District situated in

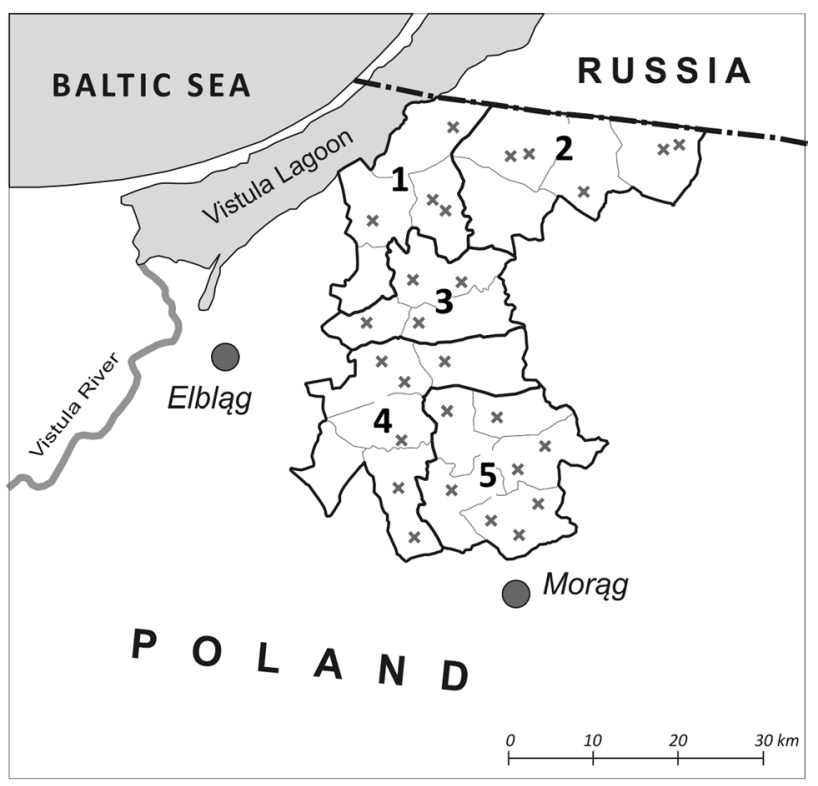

Fig. 1 Location of the study area in north-eastern Poland. The outer limits of five inventory blocks are presented along with their number designations. Distribution of belt transects $(x)$ which were used in the wild boar population census is also given

Braniewo County. These are deciduous and mixed deciduous forest types with principal forest trees of oak (Quercus robur), hornbeam (Carpinus betulus), birch (Betula sp.) and Scots pine (Pinus sylvestris) (Matuszkiewicz et al. 2020). The small forest complexes are surrounded by intensively cultivated farmland, predominantly various cereal species (56\%) followed by meadows and pastures which constitute $23 \%$ of the total area of cultivated fields and rapeseed (17\%) (Bobek et al. 2017).

The study area is inhabited by wild boar, roe deer (Capreolus capreolus), red deer (Cervus elaphus) and moose (Alces alces). Game management is performed by 14 hunting clubs in 21 hunting districts and it is supervised by the local state forest service. The study area includes all-year home ranges of the wild boar population and its characterized by seasonal changes in the availability of potential forage and hidingthermal cover (Bobek and Czyż 2015). As a result of the seasonal movement of wild boar, the number of these animal harvested in different seasons in a year differs widely among particular hunting districts.

Since 2017, the population of wild boar living in the study area is under ASF pressure (Pejsak et al. 2018).

\section{Methods}

The material for the study represents two consecutive hunting seasons: 2012/2013 and 2013/2014. 
The population of wild boar was estimated by a driving census with 27 belt transects with a total area of $27.6 \mathrm{~km}^{2}$ (February 2013) and with 21 belt transects covering $21.3 \mathrm{~km}^{2}$ in February 2014. The belt transects were located in systematic placement. Each belt transect was composed of four forest compartments adjacent to one another along their shorter sides ranging from 350 to $400 \mathrm{~m}$. The area of belt transects varied from $0.82 \mathrm{~km}^{2}$ to $1.38 \mathrm{~km}^{2}$ and was $1.02 \pm 0.29 \mathrm{~km}^{2}(\bar{x} \pm \mathrm{SE})$ on average. Each inventory team included 30 observers. During the performance of the belt census, the inventory team composed of 26 people formed a moving " $U$ "-shape line, made up of 10 people moving within forest compartments and 16 persons who formed two flanks located in both sides of the belt transect. In the front opposite destination line, four observers were placed. The distances between observers were satisfactory to keep visual contacts between the inventory team members. Hunting dogs were used to drive out wild boar from thickets. All wild boar leaving the driven belt transect were recorded.

The number of wild boar observed in each sampling belt was transformed into population density, i.e. number of animals per $1 \mathrm{~km}^{2}$. Shapiro-Wilk test was used to confirm the normal distribution of population density. Then, average population density (PD-1) and 95\% confidence intervals of the mean was calculated. The mean population density obtained was then multiplied by the forest study area and the population number in $2013\left(N_{t}\right)$ and in $2014\left(N_{t+1}\right)$ was estimated.

During two hunting seasons in all 21 hunting districts, a total of 101 collect hunts were performed. It was an average of only 2.4 hunts per one hunting district, and thus the number of wild boar harvested was too low to develop statistically significant relationships between the harvest rate and population density. Therefore, the forested areas of some adjacent hunting districts were pooled together to form five sampling inventory blocks-SIBs (Fig. 1).

As a result, a mean number of hunts per one sampling block increased to 9.0 and to 11.3 in the 2012/2013 and 2013/2014 hunting season respectively. Unfortunately, nonlinear regression showing relationships between population density PD-2 and harvest success index (HBI) indicated lack of significant relationships between these two variables, in 2012/2013:

$\mathrm{PD}-2=8.566 \times \operatorname{ArcTan}[(1.5449) \times \mathrm{HBI}], r=0.829$; $p=0.133 ; n=5$ and in 2013/2014:

$\mathrm{PD}-2=8.833 \times \operatorname{ArcTan}[(1.8771) \times \mathrm{HBI}], r=0.570$; $p=0.337 ; n=5$.

Therefore the data obtained from five SIBs from two consecutive years were used in such calculations. As a result the mean number of hunts per one sampling block amounted to 10.1 and the level of hunting bag so obtained was sufficient to derive the statistically significant non-linear regression between the number of wild boar harvested and the population density (see results).

An attempt was made to analyse the cumulated data of two years using general linear mixed model (GLMM). The relevant consultations were made with StatSoft Polska Sp. z o.o., a professional firm on this field. As the result of these consultations, the idea of using GLMM for the analysis of the obtained data was abandoned because of too low number of samples.

Local hunting clubs provided data pertaining to the total numbers of wild boar which were bagged in the study area and in particular hunting districts during 2012/2013 and 2013/2014 hunting seasons. These data were applied to calculate so-called hunting success index (PSI) for each sampling inventory block

PSI $=P_{1} / P_{2} \times 100$,

where $P_{1}$ is the hunting bag of wild boar in sampling inventory block during collective and individual hunts in each hunting season, and $P_{2}$ is the annual hunting bag of wild boar in the study area.

The population number obtained by the driving census $\left(N_{t} ; N_{t+1}\right)$ was then divided into particular sampling inventory blocks by using the hunting success index. Next, the population density (PD-2), i.e. the number of wild boar per $1 \mathrm{~km}^{2}$ of each sampling inventory blocks were calculated.

The data on the characteristics of collective hunts were collected between November 2012 and January 2013 and between November 2013 and January 2014. In such hunts, animals in hunting plots are chased by drivers and dogs in the direction of hunters who are located in a single line (Fruziński 1993; Briedermann 2009). The data on the number of hunters, drivers and dogs participating in each collective hunt, the number of hunting plots on which the hunt took place, the number of forest compartments in each hunting plot, and the number of wild boar bagged in each collective hunt were also obtained from the local hunting clubs. Because during collective hunts, the number of wild boar harvested is related to area of hunting plot, number of hunters, drivers and dogs (Vajas et al. 2020), further calculations involved collective hunts where 15-20 hunters, $8-12$ drivers with $3-5$ dogs took part, and the area of each hunting plot covered 3-4 forest compartments, i.e. $75-100$ hectares. For each sampling inventory block, the number of wild boar bagged in particular hunting season was determined as well as the number of hunting plots which was used for collective hunts. Then, the harvest success index (HBI) representing the number of wild boar bagged per one hunting plot was calculated:

$\mathrm{HBI}=\frac{\text { Hunting bag }}{\text { Number of hunting plots }} \times 100$.

According to Bobek et al. (2012), the population size of wild boar in February $2013\left(N_{t}\right)$ and February $2014\left(N_{t+1}\right)$ together with the hunting bag (HB) representing 2013/2014 
hunting season was employed to estimate the net annual population increase (NAP). The following formula was used:

$\mathrm{NAP}=\frac{\left(N_{t+1}-N_{t}\right)+\mathrm{HB}}{N_{t}} \times 100$,

where NAP is expressed in percent of $N_{t}$.

The relationship between the harvest success index (HBI), i.e. the number of harvested wild boar per hunting plot (independent variable) and the wild boar population density ( $N /$ $\mathrm{km}^{2}$ ) in particular sampling inventory blocks (dependent variable) was calculated with the use of non-linear regression based on the arc tangent function. The Statistica 10 software package in data processing was used.

\section{Results}

\section{Population density and hunting success}

The data from 27 belt transects showed the presence of 220 wild boar. Wild boar were not found in four samples. In the remaining 23 samples, the population density ranged from 2.58 to 18.87 individuals per $\mathrm{km}^{2}$ of forest. The data obtained from all belt transects indicates the normal distribution of population density (Shapiro-Wilk test: $W=0.9526$, $p=0.2474$ ). The mean population density (PD-1) was estimated to be $8.19 \pm 1.12$ individuals per $\mathrm{km}^{2}$ of forest $(\bar{x} \pm \mathrm{SE})$. The $95 \%$ confidence interval of the mean population density, amounted to \pm 2.81 individuals per $\mathrm{km}^{2}$ of forest, i.e. $\pm 34.3 \%$ of the mean value. The mean population density indicates that in February 2013, the number of wild boar in the study area amounted to 2.879 individuals.

During the 2012/2013 hunting season, the total number of wild boar harvested in individual and collective hunts in the area of five inventory blocks was 2646 individuals. In particular blocks, the number of harvested wild boar varied from 366 to 614 animals, which means that the hunting success index (PSI) there ranged from 13.8 to $23.2 \%$. Therefore, the number of wild boar estimated using the PSI index, and then by the population densities (PD-2) in particular inventory blocks, ranged from 397 to 668 animals and from 6.46 to 10.68 individuals $/ \mathrm{km}^{2}$ respectively (Table 1 ).

The driving of 21 belt transects performed in February 2014 showed the presence of 209 wild boar. The wild boar were present in all sampling plots, and their densities there ranged from 3.41 to 17.18 individuals $/ \mathrm{km}^{2}$, with normal distribution (Shapiro-Wilk test: $W=0.936, p=0.180$ ). The average population density (PD-1) was $10.09 \pm 1.06$ individuals $/ \mathrm{km}^{2}(\overline{x \pm} \mathrm{SE})$ which indicates the presence of 3547 wild boar in the study area in February 2014. The confidence
Table 1 Population variables of wild boar in five inventory blocks during 2012/ 2013 (A) and 2013/ 2014 (B) hunting season in north-eastern Poland

\begin{tabular}{|c|c|c|c|c|c|c|}
\hline \multirow[t]{2}{*}{ Habitat and population variables } & \multicolumn{5}{|c|}{ Inventory blocks } & \multirow[t]{2}{*}{ Total/ean* } \\
\hline & 1 & 2 & 3 & 4 & 5 & \\
\hline $\begin{array}{l}\text { Forest area in sampling inventory } \\
\text { blocks }\left(\mathrm{km}^{2}\right)\end{array}$ & 62.5 & 79.0 & 61.5 & 61.5 & 87.0 & 351.5 \\
\hline \multicolumn{7}{|c|}{ Wild boar harvested during hunting season } \\
\hline A & 595 & 514 & 366 & 557 & 614 & 2646 \\
\hline B & 710 & 751 & 474 & 734 & 808 & 3477 \\
\hline \multicolumn{7}{|l|}{ Population size $(N)$} \\
\hline A & 648 & 559 & 397 & 607 & 668 & 2879 \\
\hline $\mathrm{B}$ & 724 & 766 & 484 & 749 & 824 & 3547 \\
\hline \multicolumn{7}{|l|}{ Population density $\left(N / \mathrm{km}^{2}\right)$} \\
\hline A & 10.37 & 7.08 & 6.46 & 9.87 & 7.68 & $8.19^{*}$ \\
\hline B & 11.58 & 9.70 & 7.87 & 12.18 & 9.47 & $10.17^{*}$ \\
\hline \multicolumn{7}{|l|}{ Number of hunting plots } \\
\hline A & 47 & 47 & 38 & 38 & 53 & 223 \\
\hline B & 60 & 35 & 47 & 41 & 77 & 260 \\
\hline \multicolumn{7}{|c|}{ Wild boar harvested in collective hunts } \\
\hline A & 77 & 43 & 21 & 38 & 52 & 231 \\
\hline B & 112 & 52 & 40 & 44 & 85 & 333 \\
\hline \multicolumn{7}{|l|}{ Harvest success index (HBI) } \\
\hline A & 1.64 & 0.91 & 0.55 & 1.00 & 0.98 & $1.02 *$ \\
\hline B & 1.87 & 1.48 & 0.85 & 1.07 & 1.10 & $1.28^{*}$ \\
\hline
\end{tabular}

The harvest success index (HBI) represents the number of wild boar harvested per one hunting plot during collective hunts carried out from November to January

$*=$ mean (value with asterisk in the column is a mean) 
interval calculated for $95 \%$ of significance level was \pm 1.11 individuals $/ \mathrm{km}^{2}$ i.e. $\pm 11.0 \%$ of the mean value.

In the 2013/2014 hunting season, in both collective and individual hunts, 3477 wild boar were harvested. In particular inventory blocks, the number of harvested wild boar was diverse and ranged from 474 to 808 individuals indicating that the PSI index fluctuated there from 13.6 to $23.2 \%$. Therefore, the number of wild boar estimated with the use of the HSI index, and then by population densities in particular inventory blocks, ranged from 484 to 824 animals and from 7.87 to 12.18 individuals $/ \mathrm{km}^{2}$, respectively (Table 1).

\section{Population density and harvest success index}

During the 2012/2013 hunting season, the number of wild boar harvested during collective hunts in the study area amounted to 935 animals, of which 231 individuals were harvested in the 223 hunting plots used for calculating the harvest success index (HBI). For particular sampling inventory blocks, the value of this index fluctuated from 0.55 to 1.64 individuals, and amounted to 1.02 animals on average (Table 1). In the study area during the 2013/2014 hunting season, the hunting bag of wild boars harvested in collective hunts was 1026 animals. Calculations of the level of HBI index were based on 333 individuals harvested in 261 hunting plots. For all sampling inventory blocks, the average value of the HBI index amounted to 1.28 animals and ranged from 0.85 to 1.87 individuals (Table 1 ).

The data obtained in the two hunting seasons studied show a significant relationship between the harvest success index (HBI) and the population density (PD-2). Calculated on the basis of the results obtained in five inventory blocks for 2012/2013 and 2013/2014 hunting seasons (Fig. 2), the aforementioned relationship assumes the form of the following equation:

$\mathrm{PD}-2=9.18 \times \arctan [(1.496) \times \mathrm{HBI}]$,

$r=0.752, p=0.0342, n=10$,

where PD-2 is the population density $\left(N / \mathrm{km}^{2}\right)$ and $\mathrm{HBI}$ is the harvest success index.

\section{Dynamics of the population number}

In two years of study, the number of wild boar in the study area increased from 2879 to 3547 animals which means it grew by $23.2 \%$. The growth in population number is also reflected in the value of the harvest success index (HBI), as the number of wild boar calculated per single hunting plot increased from 1.02 to 1.28 individuals (growth by $25.5 \%$ ). The positive rate in population dynamics resulted from a lower wild boar numbers harvested than in the annual net population increase (NAP). In the studied population, the latter parameter in the 2012/2013 hunting season amounted to $115.2 \%$ of the wild boar number in February 2012. It results from calculations based on the data presented in Table 1 and from formula presented by Eq. 3 (see "Methods") where the population number in February $2012\left(N_{t}\right)$ and in February $2013\left(N_{t+1}\right)$, and the number of wild boar harvested in the
Fig. 2 Relationship between the harvest success index (HBI) and the population density (PD-2) calculated on the basis of the results obtained in the sampling inventory blocks in northeastern Poland. Points $1-5$ and 6-10 represent 2012/2013 and 2013/2014 hunting seasons, respectively

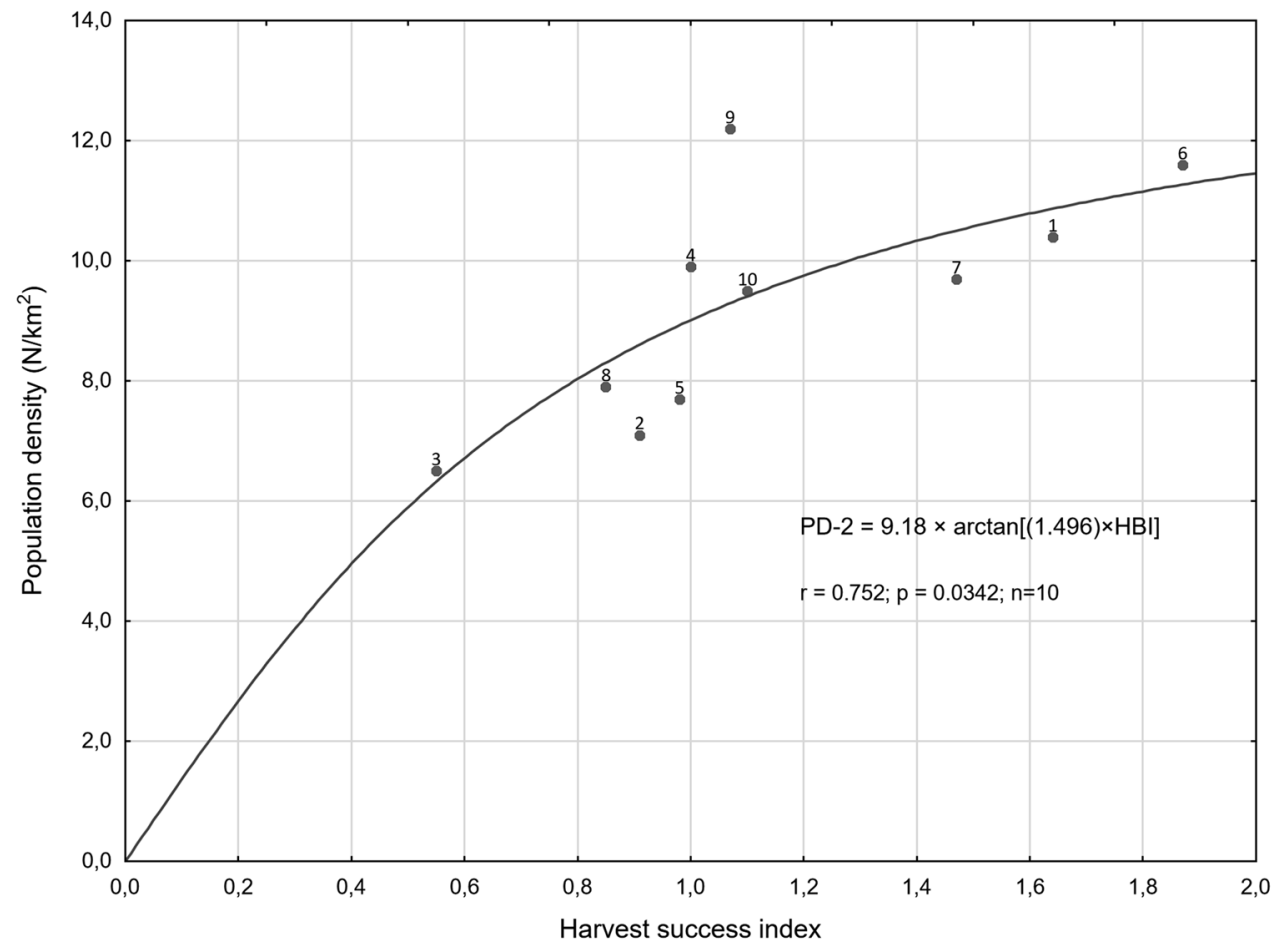


2012/2013 hunting season (HB) were substituted. The value of NAP per number of wild boar amounted to 3314 individuals, while the harvest in the period was much lower reaching only 2646 individuals.

\section{Discussion}

\section{Demographic variables and research methods used}

The increase in the number of wild boar in the study area was shaped by the lower harvest rate than the number of animals representing the net annual population increase (NAP). This high value of NAP (115.2\%) is an effect of the intensive rate of reproduction of wild boar among adults and yearling females (Albrycht et al. 2016) resulting from their access to high protein fodder in farmlands and forest habitats. In non-fragmented coniferous forest situated in south-western Poland, the NAP value is much lower and fluctuates within $52.0-77.0 \%$ range of the population numbers during the hunting season (Bobek et al. 2012). In this area, the forest food resources available to wild boar show very low nutritive value and the animals had limited access to farmlands (Merta et al. 2014).

It has been suggested in many publications that the harvest rate is positively correlated with the population number (Boitani et al 1994; Fernandez-Llario et al. 2003; Sarasa and Sarasa 2013). Therefore, distributing wild boar numbers by using the harvest success index (HBI) into particular sampling inventory blocks should properly reflect the local population densities. The correlation $(r=0.752)$ obtained in the study area indicates that almost $60 \%$ of the variation in population density is explained by the harvest success index (HBI) pertaining to the number of bagged wild boar calculated per single hunting plot.

The value of hunting bag in collective hunts depends on the size of the hunting plot and the number of hunters, dogs and drivers participating in the hunt (Vajas et al. 2020). For technical reasons it was impossible to perform analysis based on equal standard pertaining to the number of people and dogs participating in particular hunts and to the area of hunting plots. Nevertheless, the hunts were selected where the above mentioned variables showed similar values.

Excluding guessestimation on number of wild boar reported by hunters, there are ten or so objective method for determining population density of this species (Engeman et al. 2013; Keuling et al. 2018). Unfortunately, these are rarely and unwillingly used in scientific research and management practice in wild boar. It may be caused by their high cost, the large amount of labour required and also by the administrative barriers (Massei et al. 2015; Keuling et al. 2016). The small number of wildlife biologists and game managers with professional experience in the method of estimating wildlife numbers may be another factor.

During last decade only a few publication have reported that the local densities of free-living European wild boar population ranged from 0.7 to 14.0 individuals per $\mathrm{km}^{2}$ (Ebert et al. 2012; Plhal et al. 2014; Focardi et al 2016; Massei et al. 2018; Vicente et al. 2019). Therefore, the population density of this species in the study area (8.19-10.09 individuals per $\mathrm{km}^{2}$ ) fits into the upper interval of local densities in various regions of Europe.

\section{Future perspectives of collective hunts}

Increasing wild boar population density is the main risk factor in the occurrence of ASF within the population of the species and in pig industry (More et al. 2018; Podgórski et al. 2020). Therefore, the Polish Ministry of Agriculture and Rural Development issued a regulation imposing on hunters to reduce the population density of wild boar in the whole country to the level of $0.1-0.5$ individuals per $1 \mathrm{~km}^{2}$ (Jurgiel 2016). Unfortunately, because the number of wild boar in Poland provided by hunters are based upon guessestimation, it is not possible to find out to what extent the population has been reduced. The relationship between the wild boar population density and the harvest figure of that species in collective hunts may fill up this gap.

In Poland during a single hunting season, collective hunts can involve some 125,000 hunting plots used by 126 thousand hunters (Bobek et al. 2017; Central Statistical Poland 2020). Each collective hunt has documentation of the number of bagged wild boar and the numbers of participating hunters and drivers. If such documentation is supplemented by the numbers and areas of hunting plots, this would be a complete set of data needed as the basis for estimating wild boar numbers at national level.

At present, none of EU countries have reliable data on the population size of wild boar and the numbers of the species reported are sometimes still based on guess estimations (Apollonio et al. 2010). Setting a threshold for wild boar density which would lower the level of occurrence, and the rate of ASF expansion requires developing a new, easy, inexpensive and objective methods to estimate population number of wild boar at country level. The collective hunts organized widely across Europe could be used for this purpose (Boklund et al. 2018). This method of hunts is currently used for estimating densities of local populations of wild boar in Poland (see presented paper) and Spain (Vicente et al. 2019). However, the algorithms for calculations pertaininf to the analyses of the obtained data are in these two countries only. Therefore, for a wider application of the method, uniform criteria of data collection must be developed for distinct variants of collective hunts performed in particular countries of the European Union. 


\section{Conclusions}

The relationship developed in the study area between the harvest success index (HBI) and the population density is useful to learn about the numbers of wild boar living in a given hunting district throughout the whole hunting season. However, the above solution requires meeting two conditions. The first condition is the increase the number of collect hunts per district from 2.4 (the present number) to around 10 (the average for sampling inventory blocks (see "Methods"). The allocation of 10 days to this type of hunts is possible, as in each hunting season the collect hunts can be carried out in 120 subsequent days (from October to January). The second condition involves the adherence of collect hunts to standards regulating the numbers of persons and hunting dogs participating in the hunt and regulating the areas of hunting plots. The obtained population number should then be used to establish the level of the hunting bag in the subsequent hunting season. The depopulation of wild boar in the study area can be effectively performed when the harvest rate level (HB) is higher than the value of the net annual population increase (NAP).

The relationship between the harvest success index and the population density obtained in the presented study regards fragmented forest. It is probably different in nonfragmented lowland and mountain forest and depends on the proportion of deciduous and coniferous forest types.

Acknowledgements We would like to thank the State Forest Service and local hunting clubs for their skilful help during the fieldwork. The study was supported by the Polish Wildlife Foundation within program "Resolving conflicts between wildlife and man". We are grateful to StatSoft co. for statistical consulting.

Open Access This article is licensed under a Creative Commons Attribution 4.0 International License, which permits use, sharing, adaptation, distribution and reproduction in any medium or format, as long as you give appropriate credit to the original author(s) and the source, provide a link to the Creative Commons licence, and indicate if changes were made. The images or other third party material in this article are included in the article's Creative Commons licence, unless indicated otherwise in a credit line to the material. If material is not included in the article's Creative Commons licence and your intended use is not permitted by statutory regulation or exceeds the permitted use, you will need to obtain permission directly from the copyright holder. To view a copy of this licence, visit http://creativecommons.org/licenses/by/4.0/.

\section{References}

Acevedo P, Escudero MA, Munoz R, Gortazar Ch (2006) Factors affecting wild boar abundance across an environmental gradient in Spain. Acta Theriol 51(3):327-336

Albrycht M, Merta D, Bobek J, Ulejczyk S (2016) The demographic pattern of wild boar (Sus scrofa) inhabiting fragmented forest in north-eastern Poland. Balt for 22:59-66
Apollonio M, Andersen RP, Putman RJ (eds) (2010) European ungulates and their management in the 21st century. Cambridge University Press, Cambridge

Bobek B, Merta M, Furtek J, Wojciuch-Płoskonka M, Kopeć K, Maślanka J, Ziobrowski M (2013) Population dynamics of wild ungulates in various regions of Poland estimated by different methods. Studia i Materiały CEPL w Rogowie 36(3):88-101

Bobek B, Furtek J, Wojciuch-Płoskonka M (2017) Inwentaryzacja dzików przy pomocy wyników polowań zbiorowych. Las Polski 9:18-19

Bobek B, Czyż A (eds.) (2015) Gospodarka łowiecka populacją dzika w mozaice polno-leśnej nadleśnictw położonych w północnozachodniej części Regionalnej Dyrekcji Lasów Państwowych w Olsztynie. Forest District Zaporowo, 2015

Bobek B, Merta M, Furtek J (2012) The dynamics of wild boar population numbers in the lowland forest of south-western Poland. In: IXth international symposium wild boar and other suids, Sept 2-6. Abstracts. Hannover, Germany, p 39

Boitani L, Mattei L, Nonis D, Corsi F (1994) Spatial and activity pattern of wild boars in Tuscany. J Mammal 75:600-612

Boklund A, Cay B, Depner K, Földi Z, Guberti V, Masiulis M, Miteva A, More S, Olsevskis E, Šatrán P, Spiridon M, Stahl K, Thulke H-H, Viltrop A, Wozniakowski G, Broglia A, Cortinas Abrahantes J, Dhollander S, Gogin A, Verdonck F, Amato L, Papanikolaou A, Gortázar C (2018) Scientific report on the epidemiological analyse s of African swine fever in the European Union (November 2017 until November 2018). EFSA J 16(11):e05494. https://doi. org/10.2903/j.efsa.2018.5494

Briedermann L (2009) Schwarzwild. Kosmos, Stuttgart

Central Statistical Poland (2020) Statistical yearbook of forestry. Warsaw, Poland

Charmier-Ciemiński W, Ciszewski R, Kopeć K (2009) Characteristics of wild boar (Sus scrofa) population and its conflict with man in Spit of Vistula River. Pages 153-160. In: Bobek B, Mikoś J, Wasilewski R (eds) Management and conservation of wildlife in eastern Pomerania-northeastern Poland. Polskie Towarzystwo Leśne, Gdańsk 2009. In Polish with English summary

Cwynar P, Stoikov J, Wlazlak K (2019) African swine fever status in Europe. Viruses 11(4):310-317

Ebert C, Knauer F, Spielberger B, Thiele B (2012) Estimating wild boar Sus scrofa population size using fecal DNA and capturerecapture modelling. Wildl Biol 18(2):142-152

Engeman RM, Massei G, Sage M, Gentle MN (2013) Monitoring wild pig populations: a review of methods. Environ Sci Pollut Res 20:8077-8091

Fernandez-Llario P, Matoes-Quesoda PM, Silveno A, Santos P (2003) Habitat effects and shooting techniques on two wild boar (Sus scrofa) populations in Spain and Portugal. Z Jagdwiss 49:120-129

Fernandez-Lopez J, Acevedo P, Blanco-Aguiar JA, Vicente J (2020) Analysis of wild boar-domestic pig interface in Europe: preliminary analysis. EFSA Support Publ. https://doi.org/10.2903/sp.efsa. 2020.EN-1834

Flis M (2020) Spreading routes of African swine fever in Poland 2019. Życie Weterynaryjne 95(3):176-178

Focardi S, Franzetti H, Franzetti B, La Morgia V, Montanaro P, Riga F, Calabrese A, Ronchi F, Aragino P, Scacco M, Calmanti R (2016) Yes we can! Estimate wild boar populations. In: XIth international symposium on wild boar and other suids. Sept 5-8. Abstracts. Luxemburg, p 11

Fruziński B (1993) Dzik. Wydawnictwo Anton-5. Warszawa, Poland.

Guinat C, Gogin A, Biome S, Keil G, Pollin R, Pfeiffer DU, Dixon $\mathrm{L}$ (2016) Transmission routes of African swine fever virus to domestic pigs: current knowledge and future research. Vet Rec 178(11):262-267

Imperio S, Ferrante M, Grignetti A, Santini G, Focardi S (2010) Investigating population dynamics in ungulates: do hunting statistics 
make up a good index of population abundance? Wildl Biol 16(2):205-214

Jurgiel K (2016) Rozporządzenie Ministra Rolnictwa I Rozwoju Wsi z dnia 19 lutego $2016 \mathrm{w}$ sprawie zarządzenia odstrzału sanitarnego dzików. Journal of Laws of 24 February 2016, utem 229, elase 1

Keuling O, Strauss E, Siebert U (2016) Regulating wild boar populations is "somebody else's problem". Human dimension in wildlife management. Sci Total Environ 554-555:311-319

Keuling O, Sange M, Acevedo P, Podgórski T, Smith G, Scandura M, Apollonio M, Ferroglio E, Vicente J (2018) Guidance on estimation of wild boar population abundance and density: methods, challenges, possibilities. Eur Food Saf Auth 1449:1-48

Massei G, Kindberg J, Licoppe A, Gačić D, Šprem N, Kamler J, Baubet E, Hohmann U, Monaco A, Ozoliņš J, Cellina S, Podgórski T, Fonseca C, Markov N, Pokorny B, Rosell C, Náhlik A (2015) Wild boar populations up, numbers of hunters down? A review of trends and implications for Europe. Pest Manag Sci 71:492-500

Massei G, Coats J, Lambert MS, Pietravalle S, Gill R, Cowan D (2018) Camera traps and activity signs to estimate wild boar density and derive abundance indices: Camera traps to estimate wild boar density. Pest Manag Sci 74(4):853-860

Matuszkiewicz W, Sikorski P, Szwed W, Wierzba M (2020) Zbiorowiska roślinne Polski. PWN, Warszawa

Merta D, Mocała P, Pomykacz M, Frąckowiak W (2014) Autumnwinter diet and fat reserves of wild boars (Sus scrofa) inhabiting forest and forest-farmland environment in south-western Poland. Folia Zool 63(2):95-102

More S, Miranda MA, Bicout D, Bøtner A, Butterworth A, Calistri P, Edwards S, Garin-Bastuji B, Good M, Michel V, Raj M, Saxmose Nielsen S, Sihvonen L, Spoolder H, Stegeman JA, Velarde A, Willeberg P, Winckler C, Depner K, Guberti V, Masiulis M, Olsevskis E, Satran P, Spiridon M, Thulke H-H, Vilrop A, Wozniakowski G, Bau A, Broglia A, Cortiñas Abrahantes J, Dhollander S, Gogin A, Muñoz Gajardo I, Verdonck F, Amato L, Gortázar Schmidt C (2018) African swine fever in wild boar. EFSA J 16(7):5344. https://doi.org/10.2903/j.efsa.2018.5344

Okarma H, Tomek A (2008) Łowiectwo. Wydawnictwo EdukacyjnoNaukowe, Kraków, Poland, p 504

Pejsak Z, Niemczuk K, Frant M, Mazur M, Pomorska-Mól M, ZiętekBarszcz A, Bocian Ł, Łyjak M, Borowska D, Woźniakowski G
(2018) Four years of African swine fever in Poland New insights into epidemiology and prognosis of future disease spread. Pol J Vet Sci 21(4):835-841

Plhal R, Kamler J, Homolka M (2014) Faecal pellet group counting as a promising method of wild boar population density estimation. Acta Theriol 59(4):561-569

Podgórski T, Borowik T, Łyjak M, Woźniakowski G (2020) Spatial epidemiology of African swine fever: host, landscape and anthropogenic drivers of disease occurrence in wild boar. Prev Vet Med 177:104691

Przybylski A (2015) Dzik, praktyczne zasady gospodarowania populacją. Zachodni Poradnik Łowiecki, Piła, Poland, p 144

Pucek Z, Bobek B, Łabudzki L, Miłkowski M, Morow K, Tomek A (1975) Estimates of density and number of angulates. Pol Ecol Stud 1(2):121-135

Sarasa M, Sarasa JA (2013) Intensive monitoring suggests population oscilation and migration in wild boar Sus scrofa in the Pyrenees. Anim Biodivers Conserv 36(1):79-88

Śmietanka K, Woźniakowski G, Kozak E, Niemczuk K, Frączyk M, Bocian Ł, Kowalczyk A, Pejsak Z (2016) African swine fever epidemic, Poland 2014-2015. Emerg Infect Dis 22:1201-1207

Starkel L (1991) Geografia Polski Środowisko Przyrodnicze. PWN, Warszawa

Vajas P, Calenge C, Richard E, Fattebert J, Rousset C, Saïd S, Baubet É (2020) Many, large and early: hunting pressure on wild boar relates to simple metrics of hunting effort. Sci Total Environ 698:134251

Vicente J, Palencia P, Plhal R, Blanco-Aguiar AJ, Laguna E, Soriguer R, López JF, Podgórski T, Petrović K, Apollonio M, Scandura M, Ferroglio E, Zanet S, Brivio F, Keuling O, Smith GC, Guibert M, Villanúa D, Rosell C, Colomer J, Armenteros JÁ, Quirós PG, Palacios OH, Ferreres J, Torres JA, Pareja P, Martínez-Carrasco C, Fafián AJ, Escribano F, Esteve C, Acevedo P (2019) Harmonization of the use of hunting statistics for wild boar density estimation in different study areas. EFSA Support Publ 16(9):1706E. https://doi.org/10.2903/sp.efsa.2019.EN-1706

Woś A (1999) Klimat Polski. PWN, Warszawa

Publisher's Note Springer Nature remains neutral with regard to jurisdictional claims in published maps and institutional affiliations. 